Institute of $\mathbf{F}_{\text {ood and }} \mathbf{A}_{\text {gricultural }} \mathbf{S}_{\text {ciences }}$

\title{
Asian Cockroach, Blattella asahinai Mizukubo (Insecta: Blattodea: Blattellidae) ${ }^{1}$
}

Dina L. Richman ${ }^{2}$

\section{Introduction}

The Asian cockroach was identified as a newly introduced species to the United States in 1986 when a professional pest control operator collected these insects in Lakeland, Florida. He referred to them as German cockroaches, Blattella germanica (L.), but noted that their behavior was unlike any other German cockroaches that he had previously encountered. Upon further investigation the cockroaches were found to be B. asahinai, Asian cockroaches.

\section{Distribution and Habits}

The Asian cockroach was first described in 1981 from insects collected on Okinawa Island, Japan. It is most likely that B. asahinai was introduced into the United States through imports from Japan. Since the first identification of B. asahinai in Lakeland (Polk County), it has been reported from Marion County in central Florida to Broward County in southwest Florida.

The primary habitat of the Asian cockroach is outdoors in shaded mulched or composted areas, such as landscaping and gardens, where fresh plant litter accumulates. Populations of 30,000 to 250,000 insects per acre have been reported. Members of this species are strong fliers, unlike their close relative, the German cockroach. They may invade structures but indoor infestations are rare occurrences. They become active at sundown and are attracted to light-colored surfaces and brightly lit areas. Adults will take flight during the day if disturbed. The presence of this pest is obvious since their peak activity period coincides with our leisure time.

\section{Description}

Asian cockroaches are almost identical to German cockroaches. Chemical analysis by gas chromatography will confirm the species. However, there are also slight morphological differences between $B$. asahinai and B. germanica. Asian cockroach adults have longer and narrower wings than those of German cockroaches.

There are also differences between the species in the shape of the male tergal glands. Asian cockroach females produce smaller egg capsules and nymphs are smaller than that of German cockroaches. Asian

1. This document is EENY-120 one of a series of Featured Creatures from the Entomology and Nematology Department, Florida Cooperative Extension Service, Institute of Food and Agricultural Sciences, University of Florida. Published: January 2000. Revised: July 2000. This document is also available on Featured Creatures Website at http://creatures.ifas.ufl.edu. Please visit the EDIS Website at http://edis.ifas.ufl.edu. Additional information on these organisms, including many color photographs, is available at the Entomology and Nematology Department website at http://entnemdept.ifas.ufl.edu/.

2. Dina L. Richman, graduate assistant, Entomology and Nematology Department, Institute of Food and Agricultural Sciences, University of Florida, Gainesville, FL 32611.

The Institute of Food and Agricultural Sciences is an equal opportunity/affirmative action employer authorized to provide research, educational information and other services only to individuals and institutions that function without regard to race, color, sex, age, handicap, or national origin. For information on obtaining other extension publications, contact your county Cooperative Extension Service office. Florida Cooperative Extension Service/Institute of Food and Agricultural Sciences/University of Florida/Christine Taylor Waddill, Dean. 


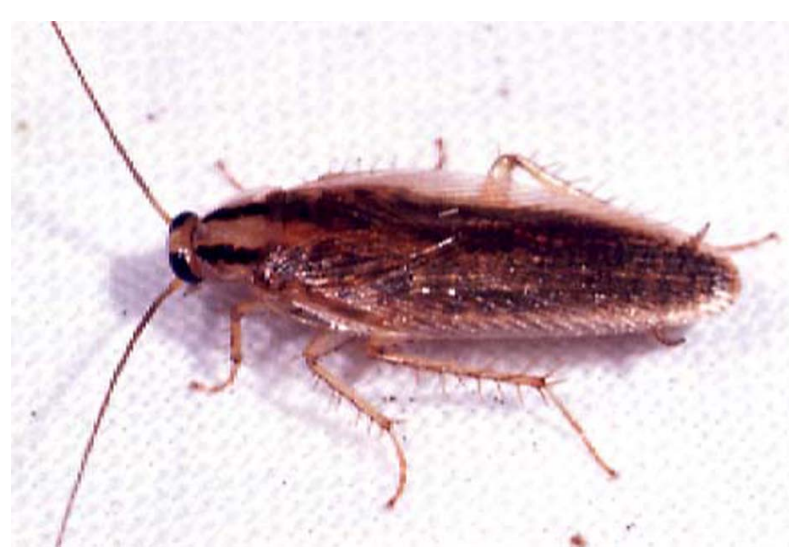

Figure 1. Adult male Asian cockroach, Blattella asahinai Mizukubo. Credits: Paul M. Choate, University of Florida

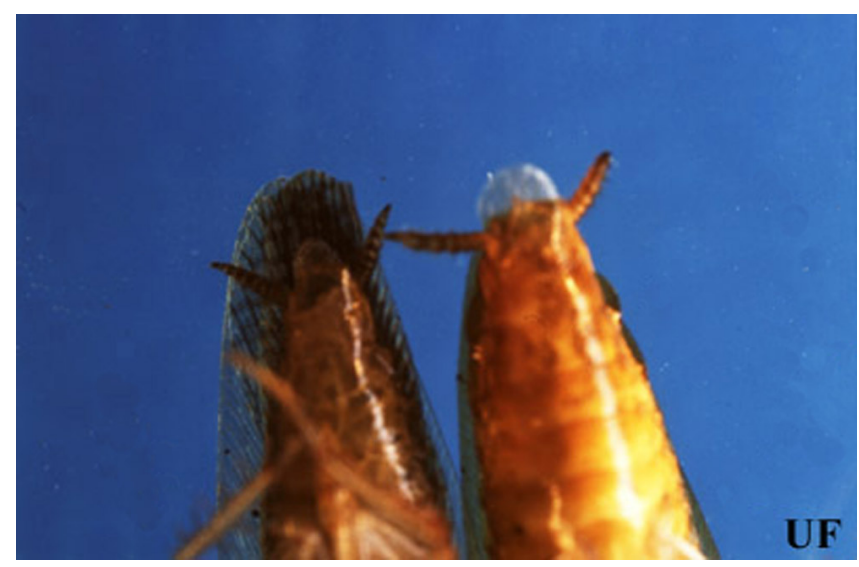

Figure 2. Adult male Asian (left), Blattella asahinai Mizukubo, and German (right), Blattella germanica (Linnaeus), cockroaches, ventral view. Notice the wings of the Asian cockroach extend past the tip of the abdomen. Credits: Dina L. Richman, University of Florida

cockroach first instars have 23 antennal segments while German cockroach first instars have 24 to 25 . Finally, margins of the abdomen and spots along the abdominal midsection of $B$. asahinai late instars appear white, whereas those areas are lightly pigmented in B. germanica.

\section{Life Cycle}

Female Asian cockroaches have a lifetime reproductive potential for producing approximately four egg capsules, each averaging 37 nymphs. Immatures take approximately 67 days to reach adulthood. Females can then live for 104 days and males can live for 49 days. Females can produce their first egg capsule 13 days after adult eclosion, and can drop another 20 days later. Adults are abundant February through May and again August through


Figure 3. Ventral view of late stages of gravid female Asian (Left), Blattella asahinai Mizukubo, and German (Right) cockroach, Blattella germanica (Linnaeus), cockroaches. Notice the wings extend past the egg capsule of the Asian cockroach, while the egg capsule extends past the wings of the German cockroach. Credits: Dina L. Richman, University of Florida

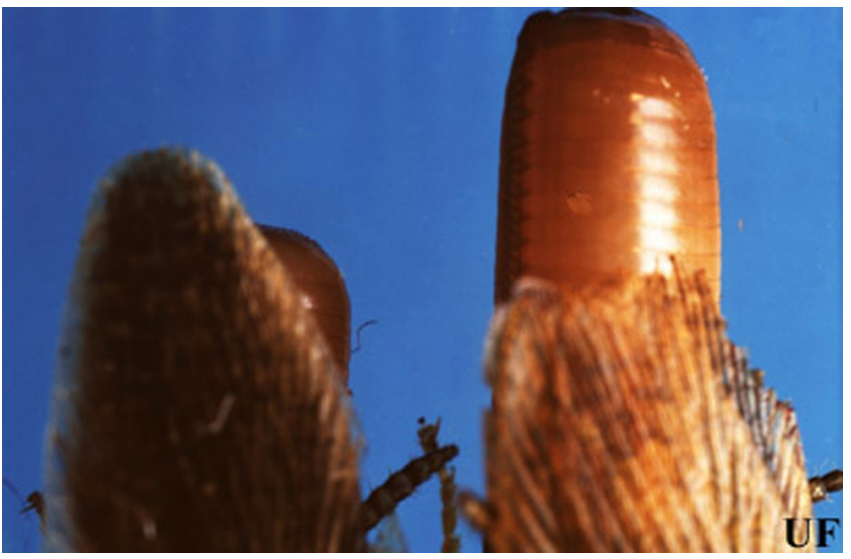

Figure 4. Dorsal views showing how wings extend past the late stage egg capsule of the Asian cockroach (left), Blattella asahinai Mizukubo, while the egg capsule extends past the wings of the German cockroach (right), Blattella germanica (Linnaeus). Credits: Dina L. Richman, University of Florida

September. Nymphs predominate May through August.

\section{Management}

Control of Asian cockroaches is difficult due to their mobility and abundance of population sites. Traditional treatments using residual sprays inside and around the perimeter of a structure are ineffective due to numerous infestations in mulched and wooded areas. Plus, adults enter homes through windows and doorways, avoiding areas typically treated for control of German cockroaches. Sodium vapor lamps for 


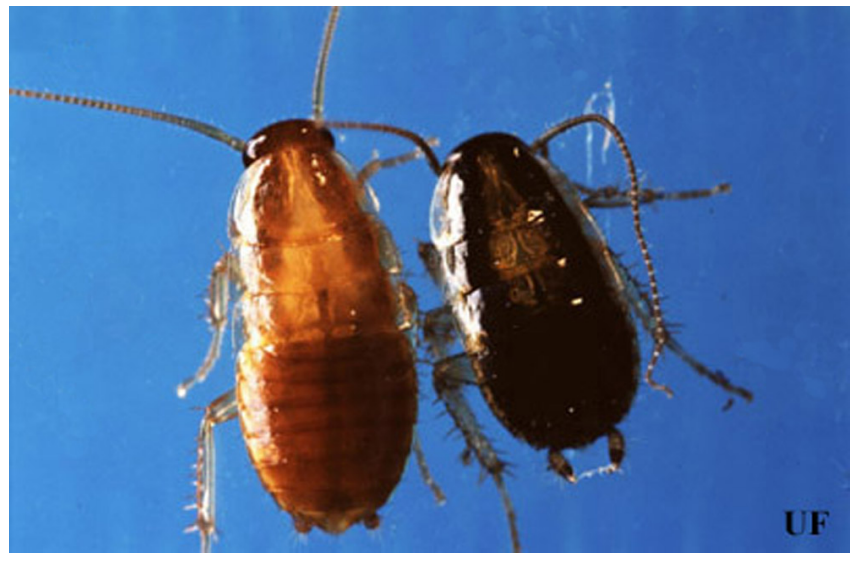

Figure 5. Early instar German (left), Blattella germanica (Linnaeus), Asian (right), Blattella asahinai Mizukubo, cockroaches, dorsal view. Credits: Dina L. Richman, University of Florida



Figure 6. Late instar German (left), Blattella germanica (Linnaeus), and Asian (right), Blattella asahinai Mizukubo, cockroaches, dorsal view. Spots along the midsection of the Asian cockroach appear white, while those areas are lightly pigmented in the German cockroach. Asian cockroach nymphs are also smaller than German cockroach nymphs. Credits: Dina L. Richman, University of Florida

security lighting and yellow incandescent bulbs for porch lighting are both less attractive to adults and would thereby reduce attraction of adult insects to lighting near buildings. Although Asian cockroaches are susceptible to all pesticides, toxic pelletized baits scattered outdoors have provided the most reliable control.

Insect Management Guide for Cockroaches

Least Toxic Methods of Cockroach Control

Asian Cockroach

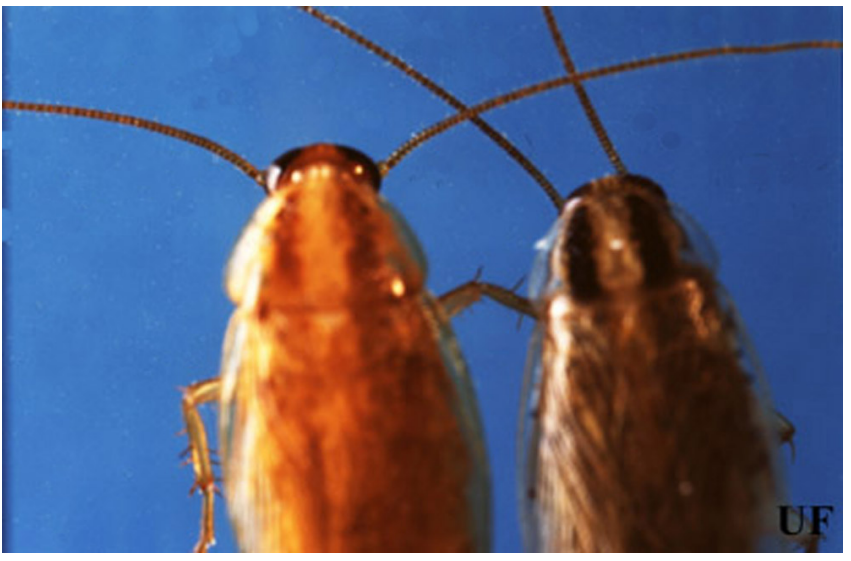

Figure 7. Adult male German (left), Blattella germanica (Linnaeus), Asian (right), Blattella asahinai Mizukubo, cockroaches, dorsal view. The pronotal stripes of the Asian cockroach are darker and more defined compared to the stripes on the German cockroach. Credits: Dina L. Richman, University of Florida

\section{Selected References}

Atkinson, T.H , P.G. Koehler, and R.S. Patterson. 1991. Reproduction and development of Blattella asahinai (Dictyoptera: Blattellidae). J. Econ. Entomol. 84: 1251-1256.

Brenner, R.J., R.S. Patterson, and P.G. Koehler. 1988. Ecology, behavior, and distribution of Blattella asahinai (Orthoptera: Blattellidae) in central Florida. Ann. Entomol. Soc. Am. 81: 432-436.

Koehler, P.G., D.E. Short and T.R. Fasulo. (1998). Pests In and Around the Home. UF/IFAS. SW-126. CD-ROM.

Ross, M.H. and D.E. Mullins. 1988. Nymphal and oothecal comparisons of Blattella asahinai and Blattella germanica (Dictyoptera: Blattellidae). J. Econ. Entomol. 81: 1645-1647.

Roth, L. M. 1987. Blattella asahinai introduced into Florida (Blatteria: Blattellidae). Psyche 93: 371-374.

Valles, S. (September 1996). German cockroach, Blattella germanica (Linnaeus). UF/IFAS Featured Creatures. EENY-2. http://edis.ifas.ufl.edu/IN128. (January 2000). 